\title{
Aging of Human Sebocytes in vitro Induced by Exposure to a Defined Hormone Environment
}

\author{
Evgenia Makrantonaki ${ }^{a, c}$ James Adjaye ${ }^{b}$ Ralf Herwig ${ }^{b}$ Thore C. Brink ${ }^{b}$ \\ Detlef Groth $^{b}$ Claus Hultschig ${ }^{b}$ Hans Lehrach ${ }^{b}$ Christos C. Zouboulis ${ }^{a, c}$ \\ a Laboratory for Biogerontology, Dermato-Pharmacology and Dermato-Endocrinology, Institute of \\ Clinical Pharmacology and Toxicology, Charité Universitätsmedizin Berlin, Campus Benjamin Franklin, and \\ ${ }^{b}$ Department of Vertebrate Genomics, Max Planck Institute for Molecular Genetics, Berlin, and \\ 'Departments of Dermatology and Immunology, Dessau Medical Center, Dessau, Germany
}

\section{Key Words}

Sebaceous gland, aging $\cdot$ Hormones, genes

The skin being a target for a plethora of hormones and also a peripheral endocrine organ by itself [1] can be affected to a large extent by the decline of hormones. For instance, the menopause in females, which is characterized by a sudden decline of sex-specific hormones, is associated with a rapid worsening of skin structure and functions, which can be, at least partially, repaired by hormone replacement therapy or local estrogen treatment [2]. Improvement of epidermal skin moisture, elasticity and skin thickness [3], enhanced production of surface lipids [4], reduction of wrinkle depth, restoration of collagen fibers [5] and increase in the collagen III/I ratio [6] have been reported. However, the role of this multiple hormone lack in the skin aging process remains to be determined. The aim of this study was to evaluate whether circulating hormones in sex- and age-specific levels account for the process of cellular aging and if so which molecular pathways are involved [7]. Human SZ95 sebocytes were treated with a hormone mixture containing growth hormone, insulin-like growth factor $1,17 \beta$-estra- diol, dehydroepiandrosterone, testosterone and progesterone in concentrations corresponding to those circulating in young (f20) and postmenopausal women (f60). Expression of the corresponding receptors was identified by RT-PCR and Western blotting, and their cellular localization was detected by immunocytochemistry. Cells incubated with all hormones mentioned above at $\mathrm{f} 60$ showed a significantly lower content of sebaceous lipids ( $\mathrm{p}<$ $0.001)$ compared to cells at $\mathrm{f} 20$ relating to in vivo observations, which have documented a decline of epidermal lipids in aged skin [7]. Increased mRNA and protein levels of $c-m y c$ and increased protein levels of FN1, which have been associated with aging in several studies [8-10], were detected in SZ95 sebocytes at 600 compared to those detected at $\mathrm{f} 20$ after 5 days of treatment [7]. Expression profiling employing a cDNA microarray composed of 15,529 cDNAs identified 899 genes with altered expression levels at $\mathrm{f} 20$ versus $\mathrm{f} 60$. Confirmation of gene regulation was performed by real-time RT-PCR. The functional annotation of these genes according to the Gene Ontology identified pathways related to mitochondrial function, oxidative stress, ubiquitin-mediated proteolysis, cell cycle, immune responses, steroid biosynthesis and phospholipid degradation (table 1) - all hallmarks of the aging process $[7,11-17]$. This is the first report describing the transcrip-

\section{KARGER}

Fax +4161306 1234

E-Mail karger@karger.ch

www.karger.com (c) 2006 S. Karger AG, Basel

$1018-8665 / 06 / 2133-0262 \$ 23.50 / 0$

Accessible online at:

www.karger.com/drm
Dr. Evgenia Makrantonaki

Departments of Dermatology and Immunology

Dessau Medical Center, Auenweg 38

DE-06847 Dessau (Germany)

Tel. +49340 501 4000, Fax +49 340501 4025, E-Mail makrant@yahoo.com 
Table 1. Signaling and metabolic pathways operative in hormonally aged sebocytes (f20 vs. f60) in vitro

\begin{tabular}{lc}
\hline Signaling pathways & Number of genes \\
\hline Steroid biosynthesis & 14 \\
C21-steroid hormone metabolism & 6 \\
Free fatty acid biosynthesis & 7 \\
Free fatty acid metabolism & 33 \\
Phospholipid degradation & 13 \\
Phosphatidylinositol-signaling pathway & 34 \\
Prostaglandin and leukotriene metabolism & 14 \\
TGF-ß-signaling pathway & 44 \\
Complement and coagulation cascade & 40 \\
Alzheimer's disease & 24 \\
Parkinson's disease & 19 \\
Huntington's disease & 14 \\
Amyotrophic lateral sclerosis & 9 \\
Dentatorubral-pallidoluysian atrophy & 9 \\
Pyruvate metabolism & 21 \\
\hline
\end{tabular}

tome of human sebaceous gland cells and its modification by a combination of major hormones in sex- and agespecific levels. Moreover, we provide an in vitro model of endogenous aging which allows a better view into the world of the hormonally affected genes and pathways in human cells. Not only the effects of one hormone as single agent were observed but the effects of a group of hormones in an effort to represent as much as possible the in vivo conditions and to give an insight into the resulting cellular and molecular processes, also altered by interactions of the corresponding hormonal signaling pathways. The identification and molecular characterization of specific genes and pathways affecting hormonal aging is a promising approach, which in the future will certainly provide further clues about the complex network involved in aging. Furthermore, understanding of the underlying mechanisms can be expected to open new strategies to deal with the various age-related diseases.

\section{References}

1 Zouboulis CC: Human skin: an independent peripheral endocrine organ. Horm Res 2000; 54:230-242.

2 Brincat MP: Hormone replacement therapy and the skin. Maturitas 2000;35:107-117.

3 Fuchs KO, Solis O, Tapawan R, Paranjpe J: The effects of an estrogen and glycolic acid cream on the facial skin of postmenopausal women: a randomized histologic study. $\mathrm{Cu}-$ tis 2003;71:481-488.

4 Sator PG, Schmidt JB, Sator MO, Huber JC, Honigsmann $\mathrm{H}$ : The influence of hormone replacement therapy on skin ageing: a pilot study. Maturitas 2001;39:43-55.

5 Schmidt JB, Binder M, Demschik G, Bieglmayer $C$, Reiner A: Treatment of skin aging with topical estrogens. Int J Dermatol 1996; 35:669-674.

6 Affinito P, Palomba S, Sorrentino C, Di Carlo C, Bifulco G, Arienzo MP, Nappi C: Effects of postmenopausal hypoestrogenism on skin collagen. Maturitas 1999;33:239-247.
7 Makrantonaki E, Adjaye J, Herwig R, Brink TC, Groth D, Hultschig C, Lehrach H, Zouboulis CC: Age-specific hormonal decline is accompanied by transcriptional changes in human sebocytes in vitro. Aging Cell 2006;5:331-344.

8 Boxer LM, Dang CV: Translocations involving $c-m y c$ and $c-m y c$ function. Oncogene 2001;20:5595-5610.

9 Grandori C, Robinson KL, Galloway DA, Swisshelm K: Functional link between Myc and the Werner gene in tumorigenesis. Cell Cycle 2004;3:22-25.

10 Labat-Robert J: Age-dependent remodeling of connective tissue: role of fibronectin and laminin. Pathol Biol (Paris) 2003;51:563568.
11 Ly DH, Lockhart DJ, Lerner RA, Schultz PG: Mitotic misregulation and human aging. Science 2000;287:2486-2492.

12 Michikawa Y, Mazzucchelli F, Bresolin N, Scarlato G, Attardi G: Aging-dependent large accumulation of point mutations in the human mtDNA control region for replication. Science 1999;286:774-779.

13 Smith JR, Pereira-Smith OM: Replicative senescence: implications for in vivo aging and tumor suppression. Science 1996;273:6367.

14 Sohal RS, Weindruch R: Oxidative stress, caloric restriction, and aging. Science 1996; 273:59-63.

15 Martin GM, Loeb LA: Ageing: mice and mitochondria. Nature 2004;429:357-359.

16 Nemoto S, Finkel T: Ageing and the mystery at Arles. Nature 2004;429:149-152.

17 Gems D, McElwee JJ: Ageing: microarraying mortality. Nature 2003;424:259-261. 